\title{
Implementation of Tissue Histopathology and Parasitic Morphometric Analysis in the Diagnosis of Myxobolus Fomenai Infection in the Skeletal Muscles Nile Tilapia
}

\author{
Hebatallah Ahmed Mahgoub ${ }^{1, *}$, Ahmed Elnaggar ${ }^{1}$, Jean-Rémy Sadeyen ${ }^{2}$ \\ ${ }^{1}$ Pathology Department, Faculty of Veterinary Medicine, Mansoura University, Egypt \\ ${ }^{2}$ The Pirbright Institute, UK \\ *Corresponding author: hebamahgoub@mans.edu.eg; heba.a.mahgoub@gmail.com
}

\begin{abstract}
Class Myxosporea includes Myxobolus parasite. Myxosporean species could infect the skeletal muscles of freshwater fish, including Nile tilapia. In this study, four Nile tilapia fish, collected from a fish farm in Dakahleya province, died and showed gross lesions of haemorrhage on the outer surface (external skeletal muscles and fins). Fish was necropsied and samples were collected for both histopathological examination and quantitative analysis of the transcriptional level of interleukin- 8 and tumour necrosis factor- $\alpha$ mRNA in selected tissues. Careful examination revealed the residence of myxospore-producing plasmodia in the affected skeletal muscles of Nile tilapia. The morphometric analysis revealed approximate morphometric results to Myxobolus fomenai. The plasmodia were detected in the skeletal muscles, focally replacing the muscle tissue and containing various developmental stages. The parasite was either surrounded with polymorphnuclear and mononuclear cells and few erythrocytes (haemorrhage), together with necrosis of the adjacent myocytes, or it was seen with sparse or without inflammatory reaction. Transcriptional analysis of interleukin-8 and tumour necrosis factor- $\alpha$ in the skeletal muscles, fins, spleen, and head-kidney revealed the slight down-regulation of interleukin- 8 and tumour necrosis factor- $\alpha$ mRNA in the skeletal muscles and their slight up-regulation in the fins of infected fish. However, their mRNA levels in the spleen and head-kidney remained unaffected by infection. Careful future histopathological examination is required to reveal the possibility of Myxobolus fomenai infection in other organs of Nile tilapia. In addition, further immunological investigation needs to be accomplished in relation to such parasitological infestation.
\end{abstract}

Keywords: Myxobolus, Muscle myxosporea, IL-8 and TNF-alpha gene expression

Cite This Article: Hebatallah Mahgoub, Ahmed Elnaggar, and Jean-Rémy Sadeyen, "Implementation of Tissue Histopathology and Parasitic Morphometric Analysis in the Diagnosis of Myxobolus Fomenai Infection in the Skeletal Muscles Nile Tilapia." American Journal of Infectious Diseases and Microbiology, vol. 5, no. 4 (2017): 137-142. doi: 10.12691/ajidm-5-4-3.

\section{Introduction}

Myxobolus parasite is classified under class Myxosporea of phylum Myxozoa [1]. Myxobolus (M.) pfeifferi, M. musculi, M. tauricus, M. pseudodispar, M. cyprini, M. lentisuturalis, Henneguya zschokkei, Thelohanellus pyrifirmis, and Thelohanellus fuhrmanni are examples of myxosporean skeletal muscle parasites of freshwater fish $[2,3,4,5]$. Abdel-Ghaffar et al. [6] detected five myxosporean species in Nile tilapia obtained from Bahr Shebin, Egypt. Zschokkella nilei, Ortholinea africanus, Triangula egyptica, Myxobolus fomenai, and Myxobolus branchiophilus were detected in the renal tubules, the urinary bladder, the kidney, the muscles (head, pectoral fin, gill arch, and pharynx), and the gill filaments, respectively. The residence of associated developmental stages might cause degeneration and/or necrosis of the infected musculature $[2,7,8,9]$, in vivo or postmortem myoliquefaction, also known as milky flesh, soft flesh, or jelly flesh $[8,9,10,11]$, fibrous connective tissue containment of the parasite $[9,10]$, or cartilaginous metaplasia of infected musculature [7], or it might become unnoticed by the immune system [9]. Such residence degrades fish flesh quality and might be of public health hazard [12].

Several research articles investigated the immune response against parasitic infection of fish, particularly myxosporean infection. Lymphocytes and granulocytes are known to be attracted to the area of myxosporean infection [13]. Antibody responses are not detected until weeks of chronic infection. Innate immune responses, like peroxidases, lysozyme, cytokines, or complement and adaptive immune responses, could be activated following myxosporean infection $[13,14,15,16,17,18]$. In this work, an accidental infection of Nile tilapia with myxosporean parasite was reported. The fish suffered sudden death and haemorrhage on the surface musculature. Samples were processed for pathological examination, morphometric analysis of the infectious agent, and organ transcriptional levels of tumour necrosis factor (TNF)- $\alpha$ and interleukin (IL)-8 mRNA as pro-inflammatory mediators [19]. 


\section{Materials and Methods}

\subsection{Fish}

Nile tilapia, 40-60 gm body weight, was obtained from a private fish farm at Dakahleya province, Egypt. All procedures for sampling were conducted under 'Guide for the Care and Use of Laboratory Animals' approved by the Ethics Committee of the Faculty of Veterinary Medicine, Mansoura University.

\subsection{Necropsy and samples collection}

Four fish, collected from a fish farm in Dakahleya province, died and showed lesions of haemorrhage on the surface skeletal muscle and fins. Apparently health (four fish) and dead fish were necropsied, and samples were collected from the affected surface skeletal muscles for histopathological examination and gene expression analysis of IL- 8 and TNF- $\alpha$. Samples were also collected from the fins, spleen, and head kidney for gene expression analysis of IL- 8 and TNF- $\alpha$.

Collected surface skeletal muscles were preserved in $20 \%$ formaldehyde. Samples were processed for haematoxylin and eosin staining at Histology laboratory, Faculty of Medicine. Slides were examined and images were taken using Apex biological microscope and the Apex Minigrab. Myxobolus species identification was based on light microscopy data of examined tissue sections, which were $5 \mu \mathrm{m}$ in thickness. Morphometric analysis was accomplished using http://rsb.info.nih.gov/ij/, where scaled images were used to make an accurate measurement of the length and width of both the spores and their polar capsules.

\subsection{RNA Extraction}

Samples for RNA extraction were preserved in RNAlater ${ }^{\circledR}$ (Qiagen). Total RNA was isolated using a Qiagen RNeasy ${ }^{\circledR}$ kit according to manufacturer's instruction. Thirty $\mathrm{mg}$ of tissue samples were placed in 2 $\mathrm{ml}$ eppendorf tubes with $600 \mu \mathrm{l}$ RT lysis buffer and were homogenized using a hand-held homogeniser. The lysate was centrifuged for $3 \mathrm{~min}$ at $13226 \mathrm{x} \mathrm{g}$. The supernatant was then removed by pipetting and transferred to a new microcentrifuge tube. Seven hundred $\mu$ of buffer RW1 were added to the RNeasy spin column, centrifuged at $8000 \mathrm{x} \mathrm{g}$ for $15 \mathrm{~s}$, and the flow-through discarded. Five hundred $\mu \mathrm{l}$ of buffer RPE were added to the column, centrifuged at $8000 \mathrm{~g}$ for $15 \mathrm{~s}$, and the flow-through discarded. Another $500 \mu \mathrm{l}$ of buffer RPE were added to the column, centrifuged at $8000 \times \mathrm{g}$ for $2 \mathrm{~min}$, and the flow-through discarded. Finally, the RNeasy spin column was placed in a new $1.5 \mathrm{ml}$ collection tube, $30-50 \mu \mathrm{l}$ of RNase-free water was added to the column membrane, and centrifuged at $8000 \mathrm{~g}$ for $1 \mathrm{~min}$ to elute the RNA.

\subsection{Quantitative Reverse Transcriptase - Polymerase Chain Reaction (qRT-PCR)}

qRT-PCR was performed using GoTaq ${ }^{\circledR}$ 1-Step RT-qPCR System, product number A6020 (Promega). The primer sequences for the selected genes are indicated in Table 1. The reaction was composed of GoTaq ${ }^{\circledR}$ qPCR Master Mix (1X), forward primer (50-300 nM), reverse primer (50-300 nM), GoScript ${ }^{\mathrm{TM}}$ RT Mix for 1-Step RT-qPCR (1X), and RNA Template (500fg-100 ng). The reaction, as recommended by the manufacturer, started with $15 \mathrm{~min}$ of reverse transcription at $37^{\circ} \mathrm{C}$. This was followed by $10 \mathrm{~min}$ of reverse transcriptase activation at $95^{\circ} \mathrm{C}, 40$ cycles of denaturation at $95^{\circ} \mathrm{C}$ for $10 \mathrm{sec}$, annealing and data collection at $60{ }^{\circ} \mathrm{C}$ for $30 \mathrm{sec}$, and extension at $72^{\circ} \mathrm{C}$ for $30 \mathrm{sec}$, and dissociation at $95^{\circ} \mathrm{C}$ for $10 \mathrm{sec}$.

\subsection{Statistical Analysis}

Statistical analysis of gene expression data in each organ was performed using student's T-test, comparing the apparently healthy fish to the diseased fish.

\section{Results}

\subsection{Gross Examination}

Gross examination of dead fish showed petechial and ecchymotic haemorrhagic areas in the pectoral fin and the adjacent skeletal muscle (Figure 1), the caudal end of the dorsal fin, the operculum, the tail, ventral fins, and the ventral aspect of Nile tilapia.

Table 1. Primer sequences for qRT-PCR.

\begin{tabular}{|c|c|}
\hline Target mRNA & Sequence \\
\hline $\begin{array}{c}\beta \text {-actin Forward primer } \\
\left(5^{\prime}-3^{\prime}\right)\end{array}$ & TGTGATGGTGGGTATGGGTCAGAA \\
\hline $\begin{array}{c}\beta \text {-actin Reverse primer } \\
\left(5^{\prime}-3^{\prime}\right)\end{array}$ & AGGTGTGATGCCAGATCTTCTCCA \\
\hline $\begin{array}{c}\text { IL-8 Forward primer } \\
\left(5^{\prime}-3^{\prime}\right)\end{array}$ & ACAGCTGTTGCAGTTTAGCGCTTC \\
\hline $\begin{array}{c}\text { IL-8 Reverse primer } \\
\left(5^{\prime}-3^{\prime}\right)\end{array}$ & AAGCACCACGATGGAGCTGACAAT \\
\hline $\begin{array}{c}\text { TNF- } \alpha \text { Forward primer } \\
\left(5^{\prime}-3^{\prime}\right)\end{array}$ & TATGGGAAGCAGCTCCACTCTGAT \\
\hline $\begin{array}{c}\text { TNF- } \alpha \text { Reverse primer } \\
\left(5^{\prime}-3^{\prime}\right)\end{array}$ & TGATAGCTGGTTGGTTTCCGTCCA \\
\hline
\end{tabular}

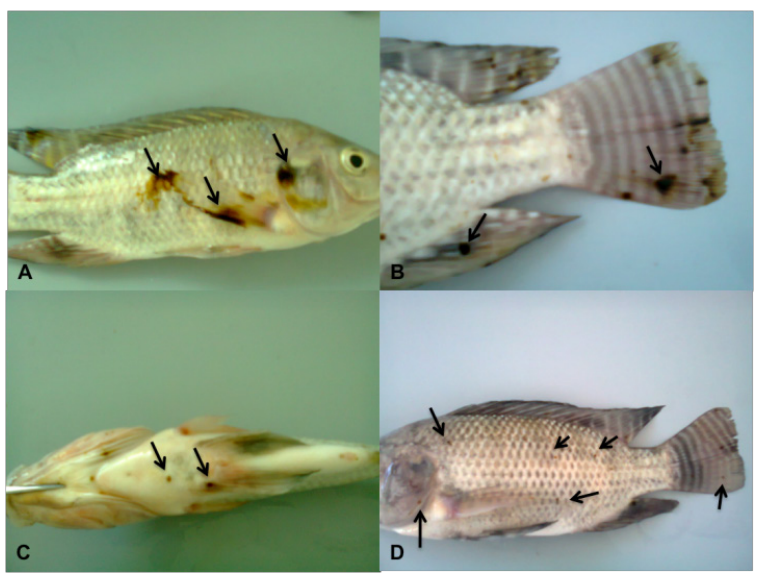

Figure 1. Gross examination of Myxobolus fomenai-infected skeletal muscle of Nile tilapia. A: Ecchymotic haemorrhage is seen in the pectoral fin and the adjacent muscle, the caudal end of the dorsal fin, and the operculum (arrows). B: The ecchymotic haemorrhage is seen in the tail and the caudal end of the dorsal fin (arrows). C: Petechial spots are seen on the ventral aspect of Nile tilapia (arrows). D: Petechial spots are seen in the tail, the dorsal muscles, and the caudal end of dorsal and ventral fins (arrows). 


\subsection{Histopathological Examination and the Morphometric Analysis}

Histopathological examination of the affected skeletal muscle showed focal replacement of the skeletal muscle fibres with mononuclear cells (mostly lymphocytes) and some free erythrocytes (haemorrhage), together with hyaline degeneration and necrosis/myomalacia of the adjacent myocytes (Figure 2). Mononuclear cells were evident in congested blood vessels and in the vicinity of muscle fibres. Perivascular oedema and damaged vascular endothelium were also evident. Focal replacement of the skeletal muscle fibres with Myxobolus species spores was also recorded, surrounded with polymorphnuclear and mononuclear cells and few erythrocytes (haemorrhage), together with congestion and necrosis of the adjacent myocytes. Myxobolus species plasmodium, containing spores, was also seen focally replacing the skeletal muscle fibre with minute or without inflammatory reaction.
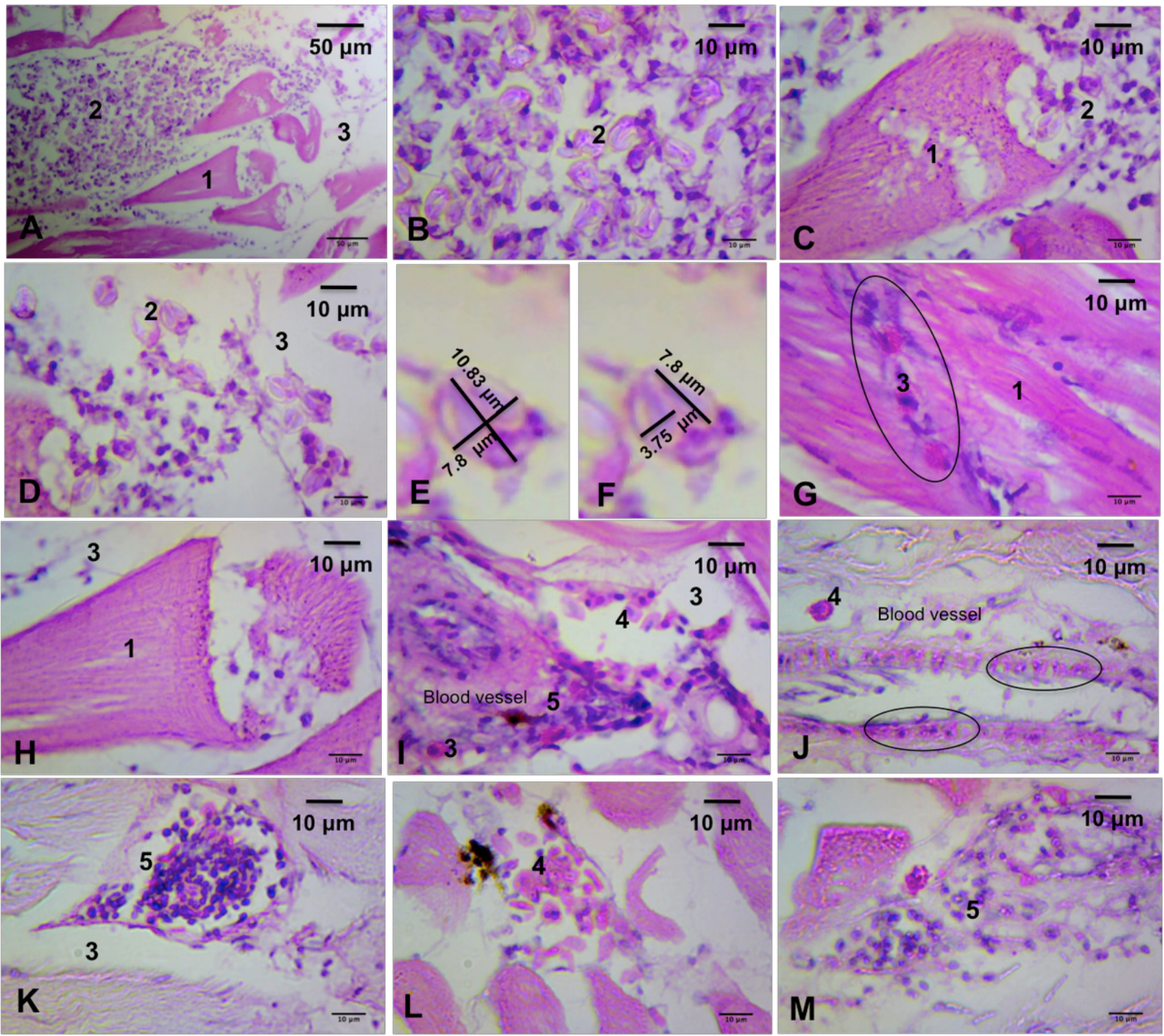

Figure 2. Histopathology of Myxobolus fomenai-infected skeletal muscle. A: Focal replacement of the skeletal muscle fibres with Myxobolus fomenai species plasmodium containing spores and developmental stages with moderate inflammatory reaction caused by plasmodium rupture, accompanied with hyaline degeneration of the surrounding muscle fibres, myomalacia, and intermuscular oedema. B: High power of A to show Myxobolus fomenai species spores and developmental stages. C: Several spores were seen disintegrating the adjacent muscle fibres causing their lysis. Leukocytes are seen in the vicinity of the damaged muscle fibres. D: Ruptured plasmodium of Myxobolus fomenai species plasmodium containing spores and developmental stages, surrounded with leukocytes. E-F: Morphometric measurement of a spore (E) and its polar capsules (F), their length and width. Polar capsules were equal, pear-shaped and occupied about two-thirds of the spore. G: Hyaline degeneration of some muscle fibres and aggregation of intermuscular erythrocytes and leukocytes (oval shape). H: Several leukocytes are seen disintegrating a muscle fibre. I: Partially obliterated blood vessel, located in the skeletal muscle fibres, with erythrocytes and hyperplastic and vacuolar changes in its wall. The blood vessel is surrounded with several erythrocytes (haemorrhage) and brownish deposits of possible haemosiderin pigment (byproduct of erythrocyte lysis). There is also oedema recorded around the affected blood vessel. J: A micrograph of an intermuscular blood vessel showing diapedesis (liberation of eryhrocytes) from the damaged blood vessel endothelium (oval shapes). K: An intermuscular blood vessel showing congestion, accumulation of intravascular mononuclear cells and erythrocytes, and vascular wall damage. Perivascular oedema is noticed. L: An intermuscular accumulation of extravasated erythrocytes and suspected haemosiderin deposition (brownish pigment). M: An intermuscular accumulation of mononuclear cells and erythrocytes. (10X: A, scale bar = 50 $\mu$ m. 40X: B; C; D; E; F; G; H; I; J; K, scale bar = $10 \mu \mathrm{m}$. 1= Muscle; 2= Myxobolus spores; 3= oedema; 4= erythrocytes; 5= leukocytes.) 
Table 2. Spore and polar capsule measurements in Myxoblus fomenai infection of Nile tilapia surface musculature.

\begin{tabular}{|c|c|c|c|c|c|c|c|c|c|c|c|c|}
\hline Parameter & Spore 1 & Spore 2 & Spore 3 & Spore 4 & Spore 5 & Spore 6 & Spore 7 & Spore 8 & Spore 9 & Spore 10 & Average & $\begin{array}{c}\text { Standard error of the } \\
\text { mean }\end{array}$ \\
\hline Spore length & 9.017 & 10.406 & 9.439 & 8.792 & 12.315 & 9.339 & 11.167 & 11.339 & 10.832 & 11.501 & 10.4147 & 0.361683979 \\
\hline Spore width & 8.516 & 7.711 & 6.472 & 6.302 & 6.217 & 7.368 & 7.227 & 7.075 & 7.826 & 8.156 & 7.287 & 0.236015974 \\
\hline $\begin{array}{c}\text { Polar capsule } \\
\text { length }\end{array}$ & 5.127 & 5.467 & 7.722 & 7.44 & 9.212 & 8.331 & 8.127 & 7.701 & 7.802 & 7.001 & 7.393 & 0.375471064 \\
\hline $\begin{array}{c}\text { Polar capsule } \\
\text { width }\end{array}$ & 2.758 & 2.664 & 2.504 & 2.814 & 2.967 & 3.675 & 3.545 & 3.736 & 3.757 & 3.418 & 3.1838 & 0.146882797 \\
\hline
\end{tabular}

Approximate morphometric results to Myxobolus fomenai were detected. The plasmodia were detected in the skeletal muscles, focally replacing the muscle tissue, containing various developmental stages (Figure 2D). The spores were pyriform in frontal view, pointed anterior end and rounded posterior one. They measured $10.41 \mu \mathrm{m}$ (average) in length and $7.28 \mu \mathrm{m}$ (average) in width (Figure 2E, Table 2). Polar capsules were equal, pearshaped, hanged at the anterior end of the spore, and occupied about three quarters of the spore. They measured $7.39 \mu \mathrm{m}$ (average) in length and $3.18 \mu \mathrm{m}$ (average) in width (Figure 2F, Table 2).

\subsection{Gene expression}

Gene expression analysis of IL-8 and TNF- $\alpha$ in the muscle, fins, spleen, and head-kidney revealed the minor down-regulation of IL-8 and TNF- $\alpha$ in the muscle and their minor up-regulation in the fins of infected fish (Figure 3). However, their transcriptional levels in the spleen and head-kidney remained unaffected by infection.
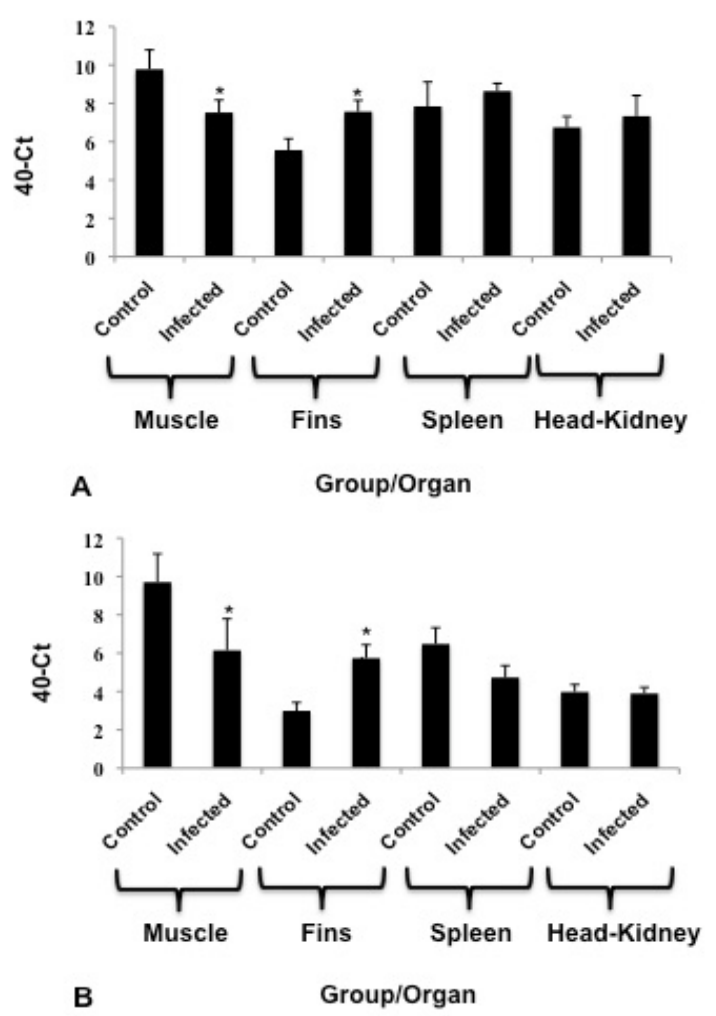

Figure 3. Organ mRNA transcription of IL- 8 and TNF- $\alpha$. A: The chart represents mRNA transcription levels of IL- 8 in muscle, fins, spleen, and head-kidney of control versus infected fish. B: The chart represents mRNA transcription levels of TNF- $\alpha$ in muscle, fins, spleen, and head-kidney of control versus infected groups. The results of each organ were analysed separately using student's T-test. $*=\mathrm{P}<0.05$.

\section{Discussion}

Myxobolus fomenai plasmodia were detected in the motor muscles of Nile tilapia, where it caused moderate myositis, myomalacia, and haemorrhage. Mononuclear cells were prevalent in the histopathological examination of the affected musculature, which denotes the chronic nature of such myositis [20], and it is also an evidence of intracellular infections [19]. Sometimes plasmodia were noticed without any recorded inflammatory reaction. Vascular hyperplastic and vacuolar changes were also evident, which caused near-obliteration of the affected blood vessel.

Our morphometric results matched what was pervious described [6,21], where the plasmodia of Myxobolus fomenai were recorded in the genal muscles of the head, motor muscles of the pectoral fin, muscles adjoining the gill arch, muscles surrounding the pharynx of Nile tilapia, intestine, and kidneys. Their spore description matched our results. However, minute differences between our morphometric results and theirs were observed in the spore length and polar capsule dimensions. This could be attributed to the location of sample collection, where Abdel-Ghaffar et al. [6,21] collected their samples from Bahr Shebin in Menofeya Province and Elminia Province, Egypt, respectively, and our fish was collected from a farm in Dakahleya Province, Egypt.

M. lentisuturalis caused severe myositis and necrosis of the dorsal epaxial muscles of goldfish, Carassius auratus auratus [2]. Molnár et al. [4] noticed the presence of $M$. musculi inside the myocyte of Iberian barbell, Luciobarbus bocagei, without eliciting any inflammatory reaction. The development of $M$. musculi, M. taurica, and M. pfeifferi occurred intracellular (inside the myocyte), attached to the collagenous dense connective tissue covering fish bones, and in the loose connective tissue among myocytes of Iberian barbell, Luciobarbus bocagei, respectively. M. cyprini of chub, Leuciscus cephalus, dorsal musculature was recorded intracellularly in the infected myocyte without causing any macroscopical alterations [3]. M. stomum infected the skeletal muscles of the buccal cavity, forming whitish cysts surrounded by host connective tissue, of blackspotted grunt, Plectorhynicus gaterinus [10]. Eiras et al. [8] reported the generalised extensive degeneration and myoliquefaction of farmed and wild flatfish, Paralichthys orbignyanus Valenciennes, infected with Myxobolus species. $M$. groenlandicus caused cartilaginous metaplasia and distortion of the skeletal muscles (at the proximal pterygiophores) of Greenland halibut, Reinhardtius 
hippoglossoides, [7]. Molnár and Székely [9] revealed different muscular locations for Myxobolus species development in Hungarian freshwater fish, causing muscular degeneration and/or necrosis. M. cyprini, M. musculi, and M. pseudodispar showed intracellular predilection in the skeletal muscles. However, M. pfeifferi, M. sandrae and $T$. hovorkai showed intermuscular predilection.

In our study, minor down-regulation of pro-inflammatory proteins (IL-8 and TNF- $\alpha$ ) mRNA transcriptional level was revealed in the muscle of infected Nile tilapia. However, their mRNA transcriptional level was slightly up-regulated in the fins of infected fish. The results were consistent for both genes in both studied organs. In a similar pattern to our study, chronic infection of gilthead sea bream, Sparus aurata L., intestine with Enteromyxum leei downregulated the expression of IL-1 $\beta$, TNF- $\alpha$, and glutathione peroxidase- 1 and upregulated $\alpha-2$ macroglobulin and heat shock $70 \mathrm{kDa}$ protein 9 (GRP-75 or mortalin) in the intestine [18]. It also downregulated growth hormone receptor-I and insulin-like growth factorI in the head kidney. In a different study using the same infectious model, IL-1 $\beta$ expression in the head kidney was upregulated 10 days postinfection [14]. However, TNF- $\alpha$ expression was downregulated from 38 days postinfection onwards. In previous literature, infection of rainbow trout, Oncorhynchus mykiss, with Tetracapsuloides bryosalmonae, the causative agent of proliferative kidney disease, upregulated the expression of TNF- $\alpha 2$, cyclooxygenase-2, and to a lesser extent transforming growth factor (TGF)- $\beta 1$ in the kidney [16]. In a different study [15], Tetracapsuloides bryosalmonae upregulated the expression of IL-6 and IL-11 in the kidney of rainbow trout in the early to advanced stage of infection. However, antimicrobial peptides (cathelicidin 1 and 2, hepcidin, and liver-expressed antimicrobial peptide-2 isoform A), anti-inflammatory markers (IL-10, TGF- $\beta 1 \mathrm{a}$, Forkhead Box P3 (FOXP3)A, FOXP3B) were markedly upregulated during clinical disease. $\mathrm{T}$ helper (1 and 2 ) immune responses (response genes and/or transcription factors) were also upregulated throughout the course of infection. Enteromyxum scophthalmi infection of turbot, Scophthalmus maximus, upregulated the local immune response (e.g. IL-17a f-1, IL-22, mannose-binding lectin-associated serine protease-3b, epidermis-type lipoxygenase 3-like, cluster designation(CD) 83 antigen, cytochrome b-245 heavy chain, lipopolysaccharide-TNF- $\alpha$ factor, and CC chemokine) and apoptotic machinery in the intestine (predilection site of infection) and downregulated the immune response (e.g. major histocompatibility complex class I antigen, interferon gamma receptor alpha chain, interferon regulatory factor 7 and 3, toll-like receptor 9, and some interferon-induced proteins), apoptotic machinery, and erythropoiesis in the spleen and kidney, 42 days post-infection [17].

Although our study didn't investigate the histopathological alteration in the grossly altered fins (pin-point haemorrhagic spots), the slightly up-regulated transcriptional level of IL-8 and TNF- $\alpha$ reflects a possible Myxobolus fomenai infection of the fins, since similar gross lesion pattern was detected in the infected musculature. Such infection could have been more recent than musculature (acute), where such suspected acute infection of the fins caused an up-regulation pro-inflammatory genes, and the recorded chronic infection of the musculature (as was revealed by the prevalence of mononuclear cells in the musculature blood vessels and in the vicinity of muscle fibres) caused their down-regulation, where such proteins up-regulation is a marker for the acute phase response following an infection [19].

Although such superficial infection of the locomotor system does not seem to be a potential cause of death, a simultaneous disease condition could have caused such recorded mortalities among Nile tilapia.

\section{Conclusion}

Our study revealed infection of Nile tilapia muscles with Myxobolus fomenai. The studied immunological parameters confirmed the existence of a recent inflammatory condition in the fins (where gross lesions of haemorrhage existed). Careful future microscopical tissue examination is required to reveal the possibility of Myxobolus fomenai infection in other organs of Nile tilapia. Furthermore, more immunological parameters need to be investigated in association with such parasitological infestation.

\section{Authors' Contributions}

Fish necropsy and careful histopathological examination were performed by HM and AE. Samples processing for RNA extraction, parasitological analysis, and statistical analysis were performed by HM. The qRTPCR assay was performed by JS.

\section{Acknowledgements}

This research did not receive any specific grant from funding agencies in the public, commercial, or not-forprofit sectors. The authors wish to thank Dr Mustafa ElAraby for his kind help in the preliminary identification of Myxobolus parasite.

\section{References}

[1] Roberts, R.J. Fish pathology. 4th ed. ed. Chichester: WileyBlackwell, 2012.

[2] Caffara, M., Raimondi, E., Florio, D., Marcer, F., Quaglio, F., Fioravanti, M.L. The life cycle of Myxobolus lentisuturalis (Myxozoa: Myxobolidae), from goldfish (Carassius auratus auratus), involves a Raabeia-type actinospore. Folia Parasitol (Praha) 2009; 56(1): 6-12.

[3] Holzer, A.S., Schachner, O. Myxosporidia and macrophage centres in chub (Leuciscus cephalus)--quantitative interactions focus on Myxobolus cyprini. Parasitology 2001; 122 Pt 1: 55-62.

[4] Molnár, K., Eszterbauer, E., Marton, S., SzÈkely, C., Eiras, J.C. Comparison of the Myxobolus fauna of common barbel from Hungary and Iberian barbel from Portugal. Dis Aquat Organ 2012; 100(3): 231-48.

[5] Molnár, K., Eszterbauer, E., Szekely, C., Dan, A., Harrach, B. Morphological and molecular biological studies on intramuscular Myxobolus spp. of cyprinid fish. J Fish Dis 2002; 25(11): 643-52.

[6] Abdel-Ghaffar, F., El-Toukhy, A., Al-Quraishy, S., Al-Rasheid, K., Abdel-Baki, A.S., Hegazy, A., et al. Five new myxosporean species (Myxozoa: Myxosporea) infecting the Nile tilapia 
Oreochromis niloticus in Bahr Shebin, Nile Tributary, Nile Delta, Egypt. Parasitol Res 2008; 103(5): 1197-205.

[7] Buchmann, K., Skovgaard, A., Kania, P.W. Myxobolus groenlandicus n. sp. (Myxozoa) distorting skeletal structures and musculature of Greenland halibut Reinhardtius hippoglossoides (Teleostei: Pleuronectidae). Dis Aquat Organ 2012; 98(2): 133-41.

[8] Eiras, J.C., J'nior, J.P., Sampaio, L.A., Robaldo, R., Abreu, P.C. Myxobolus sp. can cause in vivo myoliquefaction in the host Paralichthys orbignyanus (Osteichthyes, Paralichthydae). Dis Aquat Organ 2007; 77(3): 255-8.

[9] Molnár, K., Székely, C. Tissue preference of some myxobolids (Myxozoa: Myxosporea) from the musculature of European freshwater fishes. Dis Aquat Organ 2014; 107(3): 191-8.

[10] Ali, M.A., Abdel-Baki, A.S., Sakran, T., Entzeroth, R., AbdelGhaffar, F. Light and electron microscopic studies of Myxobolus stomum n. sp. (Myxosporea: Myxobolidae) infecting the blackspotted grunt Plectorhynicus gaterinus (Forsskal, 1775) in the Red Sea, Egypt. Parasitol Res 2003; 91(5): 390-7.

[11] Henning, S.S., Hoffman, L.C., Manley, M. A review of Kudoainduced myoliquefaction of marine fish species in South Africa and other countries. Afr J Sci 2013; $109((11 / 12))$.

[12] Elsheikha, H.M. Human health risk implication of ocular myxoboliosis in fish. Veterinary Times: Clinical Piscine 2009.

[13] Sitjà-Bobadilla, A. Fish immune response to Myxozoan parasites. Parasite 2008; 15(3): 420-5.

[14] Cuesta, A., MuÒoz, P., RodrÌguez, A., Salinas, I., Sitjł̣-Bobadilla, A., Alvarez-Pellitero, P., et al. Gilthead seabream ( Sparus aurata L.) innate defence against the parasite Enteromyxum leei (Myxozoa). Parasitology 2006; 132(Pt 1): 95-104.
[15] Gorgoglione, B., Wang, T., Secombes, C.J., Holland, J.W. Immune gene expression profiling of Proliferative Kidney Disease in rainbow trout Oncorhynchus mykiss reveals a dominance of anti-inflammatory, antibody and $\mathrm{T}$ helper cell-like activities. Vet Res 2013; 44:55.

[16] Holland, J.W., Gould, C.R., Jones, C.S., Noble, L.R., Secombes, C.J. The expression of immune-regulatory genes in rainbow trout, Oncorhynchus mykiss, during a natural outbreak of proliferative kidney disease (PKD). Parasitology 2003; 126 Suppl:S95-102.

[17] Robledo, D., Ronza, P., Harrison, P.W., Losada, A.P., Berm dez, R., Pardo, B.G., et al. RNA-seq analysis reveals significant transcriptome changes in turbot (Scophthalmus maximus) suffering severe enteromyxosis. BMC Genomics 2014; 15: 1149.

[18] Sitjà-Bobadilla, A., Calduch-Giner, J., Saera-Vila, A., Palenzuela, O., Alvarez-Pellitero, P., PÈrez-S•nchez, J. Chronic exposure to the parasite Enteromyxum leei (Myxozoa: Myxosporea) modulates the immune response and the expression of growth, redox and immune relevant genes in gilthead sea bream, Sparus aurata L. Fish Shellfish Immunol 2008; 24(5): 610-9.

[19] Murphy, K., Travers, P., Walport, M., Janeway, C. Janeway's immunobiology. 8th ed. ed. London: Garland Science ; London : Taylor \& Francis [distributor], 2012.

[20] Jones, T.C., Hunt, R.D., King, N.W. Veterinary pathology. 6th ed. ed. Baltimore, Md. ; London: Williams \& Wilkins, 1997.

[21] Abdel-Ghaffar, F., Morsy, K., El-Ganainy, S., Ahmed, M., Gamal, S., Bashtar, A.R., et al. Twelve myxosporean species of the family Myxobolidae infecting freshwater fishes of the River Nile, Egypt, with the description of four novel species. Parasitol Res 2015; 114(8): 2985-98. 